\title{
Agricultural Development Problems in a Newly Independent, War-Ravaged Country: Eritrea
}

\author{
Abubaker Osman and J A Groenewald
}

Department of Agricultural Economics, University of the Free State

\section{ABSTRACT}

Eritrea obtained independence in 1992, after a century of foreign rule and war. The agricultural sector has been unable to produce enough food for Eritrea and the situation deteriorated substantially during the war with Ethiopia. It has considerable potential for agricultural, including horticultural, production. Eritrea should therefore develop an export base built on agriculture. The rural economy should be transformed from a subsistence to a commercial economy. Agricultural policy could partially achieve this goal by developing incentives, including (nito alis) changes in land tenure systems, improvement of transport, storage and communications infrastructure, marketing services, and also extension and human capital development. Trade policy should focus on gaining access to foreign markets. The government should not attempt to take over entrepreneurial functions, instead it should focus on empowering this sector.

JEL Q10

\section{INTRODUCTION}

Eritrea came under European rule when Italy took possession of the country in 1885 and became an Italian colony a few years later. In 1936 Eritrea was incorporated, together with Abyssinia (now called Ethiopia), in a larger Italian colony of East Africa. During the colonial rule, the Italian colonisers erected irrigation works and infrastructure to help intensive agriculture by Italian colonist farmers. The Second World War terminated Italian colonial rule, and in 1951 Eritrea was incorporated in Ethiopia in accordance with a decision by the United Nations.

During the Ethiopian rule, which lasted until 1991, Eritrean infrastructure did not develop further, but instead regressed during the Revolution regime that followed the deposition of the Emperor of Ethiopia. A protracted war of insurrection against Ethiopian rule, particularly during the late 1980s, led to the establishment of the independent state of Eritrea in 1992. As difficult as the 
development of independent Eritrea would be to achieve, it was dealt another heavy blow by a border war with Ethiopia from 1996 to 1999.

Economic development, including development of agriculture, presents a great challenge. This article sets out to outline the importance of agriculture to the Eritrean economy and its development since 1992. Guidelines are suggested for future development policy. Very little data is available in terms of quantitative analysis concerning Eritrea itself. Development policy will therefore have to lean heavily on experience elsewhere. Concerted efforts are also needed to generate quantitative data and information within Eritrea itself.

\section{AGRICULTURE AND THE ERITREAN ECONOMY}

Due to the interdependence between different sectors of an economy, any simplistic assessment of the importance of a sector is bound to be misleading. Economic sectors contribute positively or negatively to the output of other sectors in the economy. In order to describe the contributions of agriculture to economic development, Brand (1969) advocated a functional classification of the contributions of the sector, involving five functions: the supply of food; contributions to trade balance; employment and labour transfer; capital transfer; and market contributions in the form of forward and backward linkages.

The paucity of economic data for Eritrea renders a full functional analysis impossible. However, available data will be presented in order to obtain at least some idea of the contributions and problems of Eritrean agriculture.

\subsection{Contribution to GDP}

The role of agriculture in the economic development of Eritrea will remain highly significant for the forseeable future. At present, eighty per cent of the population depends on agriculture for their livelihood. As can be seen from the composition of the Gross Domestic Product (GDP) the agricultural sector's contribution to GDP is much smaller than its proportion of the population, indicating that rural poverty is a real phenomenon in Eritrea. GDP data are shown in Table 1. 
Table 1 Gross Domestic Product of Eritrea by Economic Sector, 1993-1999

\begin{tabular}{||l|c|c|c|c|c|c|c|c|c|c||}
\hline \hline & \multicolumn{9}{|c|}{ Estimated Annual Product (Millions Nacfa) } & \multicolumn{2}{c|}{ Average } \\
\hline & 1992 & 1993 & 1994 & 1995 & 1996 & 1997 & 1998 & 1999 & $\begin{array}{c}\% \\
\text { Share } \\
\text { of GDP }\end{array}$ & $\begin{array}{c}\text { Annual } \\
\text { Growth } \\
\text { Rate }(\%)\end{array}$ \\
\hline Agriculture & 589.0 & 510.8 & 778.0 & 714.4 & 693.3 & 700.5 & 1412.6 & 1541.0 & 20.1 & 14.7 \\
\hline Industry & 235.3 & 399.9 & 439.9 & 613.3 & 847.3 & 1033.1 & 999.4 & 1086.6 & 15.5 & 24.4 \\
\hline Distribution & 722.1 & 1034.6 & 1255.4 & 1393.5 & 1577.3 & 1743.0 & 1583.6 & 1698.8 & 32.3 & 13.0 \\
\hline Services & 401.7 & 561.9 & 886.0 & 1000.2 & 1109.8 & 1240.9 & 1395.4 & 1568.1 & 22.8 & 21.5 \\
\hline GDP at current factor cost & 1957.2 & 2507.1 & 3395.4 & 3721.4 & 4227.7 & 4770.5 & 5390.9 & 5894.5 & 90.8 & 17.0 \\
\hline Growth (\%) & - & 28.1 & 35.4 & 9.6 & 13.6 & 12.8 & 13.0 & 9.3 & - & - \\
\hline Growth, agriculture (\%) & - & -13.3 & 52.3 & -8.2 & -3.0 & 1.0 & 101.6 & 9.1 & - & - \\
\hline Plus: Indirect taxes & 233.8 & 338.3 & 341.7 & 375.9 & 450.4 & 511.5 & 464.7 & 500.0 & 9.6 & 11.5 \\
\hline Less: Subsidies & & & & & & 43.1 & 54.5 & 57.3 & 0.33 & 15.3 \\
\hline GDP at current market price & 2190.9 & 2845.4 & 3701.1 & 4097.3 & 4678.1 & 5185.9 & 5801.2 & 6337.2 & 100.0 & 16.4 \\
\hline
\end{tabular}

Source: Ministry of Finance Eritrea, Asmara, 1999. Data for the year 1999 is preliminary 
According to Table 1, GDP at factor cost grew at an average of 17 per cent p.a. during the 1992-1999 period. There were huge fluctuations in the rate of economic growth, from a high of 35.4 per cent to a low of 9.3 per cent. Such fluctuations are to be expected in an economy in which agriculture plays a dominant role and which is largely dependent on climatic conditions. The growth of the agricultural contribution to GDP was even more variable, ranging from doubling in 1998, an increase of more than 50 per cent in 1994, to a present negative growth. The mean share of agriculture of GDP was 20 per cent.

\subsection{Supply of food}

Food security is a serious concern in the less developed world, including Eritrea. Many low-income countries are not able to meet the nutritional requirements of their people. Even in countries that do have enough available food, poorer sections of the population can nevertheless not afford it. Famine and starvation are as much functions of income and food distribution systems as of food availability (Sen, 1981). Sub-Saharan Africa, which includes Eritrea, is the world's most vulnerable region regarding food security. Although its population comprises only 25 per cent of the total of less developed countries, sub-Saharan Africa, is projected to account for 66 per cent (from 66 countries) of the inadequacy to meet its nutritional needs by 2007 (Shapouri \& Rosen, 1997: 3). Even if grain output in Eritrea would rise by 2.9 per cent per year, this increase would not be sufficient to fill the country's nutritional gap by 2007 (Shapouri \& Rosen, 1997: 52).

In general, a country's food sources consist of domestic production and commercial imports. The ability to import food commercially depends on the country's ability to maintain a trade balance by exporting alternative products. The ability of other sectors in Eritrea to generate foreign earnings through exports is rather limited at this stage. Food aid, the third component of food for many less developed countries, depends on political decisions and is in any case not sufficient to close food gaps. The ideal is for a country to develop sufficiently in order to be independent of food aid.

Failure to expand domestic food production at an equal rate to the increase in demand for food, will lead to either a resulting rise in food prices or an increase in food imports (including food aid) to increase domestic food supply, or both.

The relative importance of these two sources of supply is assessed by means of the annual physical food balance sheets prepared by the FAO. These balance sheets show estimates of total annual food supplies in physical terms. The data 
is used in Table 2 to compare domestic production with imports for 1993 to 1999.

As reflected in the data, cereals are the principal source of food in Eritrea. Imports have generally constituted a major source of food supplies during the period under consideration. For instance, from 1993 to 1995, imports on average accounted for 53.8 per cent of the supply of cereals. Then, from 1996 to 1997, it increased on average to 76.0 per cent, to decline to 21.23 per cent in 1999. The decline in the late 1990s was due to an increased production of cereals through the introduction of integrated farming systems by the Ministry of Agriculture and constraints imposed by the border war with Ethiopia. Sugar is only supplied through imports. Vegetable and crop oils and fruit on average, were imported in small quantities. Only negligible quantities of the total supply of meat and eggs were imported. Although imports of these commodities (vegetable, fruits, meat and eggs) constitute a small percentage of the total new supply, it does not mean that local supply satisfies the demand. These agricultural commodities are very scarce on the market, but the very low income of the majority of the population suppresses the demand for them.

Imports as a percentage of total consumption, fluctuated from year to year in the cases of cereals, pulses and milk.

Table 2 Source of food supply, Eritrea, 1993 - 1999 in 1000 metric tons

\begin{tabular}{||c|c|c|c|c|c|c|c|c|c||}
\hline \hline \multicolumn{10}{||c|}{ New supply from local production and imports } \\
\hline Year & Cereals & $\begin{array}{c}\text { Star- } \\
\text { chy } \\
\text { roots }\end{array}$ & Sugar & Pulses & $\begin{array}{c}\text { Vege- } \\
\text { table \& \&eat \& } \\
\text { erop oils }\end{array}$ & $\begin{array}{c}\text { Vege- } \\
\text { eggs } \\
\text { tables } \\
\text { \& fruit }\end{array}$ & Milk & $\begin{array}{c}\text { Total all } \\
\text { Commo- } \\
\text { dities }\end{array}$ \\
\hline 1993 & 203 & 124 & 2 & 27 & 31 & 25 & 28 & 44 & 484 \\
\hline 1994 & 522 & 126 & 5 & 58 & 34 & 28 & 39 & 60 & 872 \\
\hline 1995 & 269 & 122 & 10 & 60 & 38 & 30 & 34 & 57 & 620 \\
\hline 1996 & 329 & 119 & 14 & 59 & 28 & 33 & 33 & 53 & 668 \\
\hline 1997 & 419 & 127 & 26 & 60 & 24 & 29 & 36 & 60 & 781 \\
\hline 1998 & 762 & 130 & 7 & 64 & 32 & 31 & 41 & 84 & 1151 \\
\hline 1999 & 405 & 127 & 12 & 54 & 31 & 34 & 38 & 76 & 777 \\
\hline
\end{tabular}


Table 2 continued

\begin{tabular}{||c|c|c|c|c|c|c|c|c|c||}
\hline \multicolumn{10}{||c|}{ Imports as percentage of total new supply } \\
\hline Year & Cereals & $\begin{array}{c}\text { Star- } \\
\text { chy } \\
\text { roots }\end{array}$ & Sugar & Pulses & $\begin{array}{c}\text { Vege- } \\
\text { table \& } \\
\text { crop oils }\end{array}$ & $\begin{array}{c}\text { Meat \& } \\
\text { eggs }\end{array}$ & $\begin{array}{c}\text { Vege- } \\
\text { tables } \\
\text { \& fruits }\end{array}$ & Milk & $\begin{array}{c}\text { Total all } \\
\text { Commo- } \\
\text { dities }\end{array}$ \\
\hline 1993 & 57.14 & 0 & 100.00 & 37.04 & 22.58 & 0 & 0 & 0 & 27.98 \\
\hline 1994 & 50.38 & 0 & 100.00 & 25.86 & 11.76 & 0 & 0 & 23.33 & 34.52 \\
\hline 1995 & 54.28 & 0 & 100.00 & 6.7 & 5.26 & 0 & 2.94 & 17.54 & 27.90 \\
\hline 1996 & 74.77 & 0 & 100.00 & 13.56 & 3.57 & 0 & 3.03 & 0 & 40.42 \\
\hline 1997 & 77.33 & 0 & 100.00 & 18.33 & 0.0 & 0 & 2.78 & 3.33 & 46.61 \\
\hline 1998 & 41.08 & 0 & 100.00 & 6.25 & 9.38 & 0 & 7.32 & 22.62 & 30.32 \\
\hline 1999 & 21.23 & 0 & 100.00 & 7.41 & 12.90 & 0 & 13.16 & 11.84 & 15.44 \\
\hline
\end{tabular}

${ }^{\mathrm{T}}$ Milk All dairy products including fresh milk, cheese, butter, sour milk, etc. converted to milk equivalent tons

Source: Data for production and imports taken from the food balance sheets prepared by FAO for the period 1993 - 1999

Cereals constitute the main staple food and the need to import these causes a serious drain on the country's foreign currency. At the same time, most of the population - like the poor elsewhere in the world - spend a high proportion of their income on survival needs, of which food is the major component. Eritrea has therefore been unable to import capital goods and attract foreign investment. In addition, the majority of the population receives inadequate nutrition. This severely affects people's health and productivity of workers. Important nutrition and health are prerequisites for improved productivity.

\subsection{Agricultural trade}

As outlined above, the agricultural sector of Eritrea, whilst being the livelihood of 80 percent of the population, earns only 20 per cent of the GDP and produces insufficient food for the population. This causes Eritrea to spend a large portion of the available funds on food imports. It is safe to state that a large part of the population earns incomes that are insufficient to purchase enough food; this is evident from the widespread malnutrition observed in Eritrea.

The major agricultural commodities imported include sugar, wheat, teff (which is used as a cereal for human consumption), coffee, wheat flour, maize and sorghum. The main exports are fish (fresh or chilled), vegetables and live animals especially goats. The commodities imported serve basic food needs of the population while the agricultural commodities that are exported earn foreign currency. 
According to Table 335.7 per cent of imports originate from Western Europe, whilst originate from the Middle East (mainly Saudi-Arabia, United Arab Emirates, Yemen, Jordan and Israel). The Horn of Africa constitutes the next source of imports with an average share of 9.6 per cent which has declined from 14.7 per cent since the late 1990s. Imports from Central and East Asia hail mainly from Japan, South Korea, Singapore, India and China. Imports from the United States constitute only 2.8 per cent while the share from Latin America and North Africa is almost negligible.

Table 3 Origin of imports to Eritrea, 1993 - 1999 (Percentage Share)

\begin{tabular}{||l|c|c|c|c|c|c|c|c||}
\hline \multirow{2}{*}{ Origin } & \multicolumn{6}{|c|}{ Year } & \multirow{2}{*}{ Average } \\
\cline { 2 - 9 } & $\mathbf{1 9 9 3}$ & $\mathbf{1 9 9 4}$ & $\mathbf{1 9 9 5}$ & $\mathbf{1 9 9 6}$ & $\mathbf{1 9 9 7}$ & $\mathbf{1 9 9 8}$ & $\mathbf{1 9 9 9}$ & A \\
\hline Western Europe & 31.4 & 33.0 & 43.2 & 33.3 & 35 & 38.2 & 36.4 & 35.7 \\
\hline Central and East Asia & 2.2 & NA & 6.9 & 12.6 & 12.2 & 12.8 & 8.0 & 7.8 \\
\hline Middle East & 38.2 & 26.5 & 29.7 & 27.3 & 29.2 & 32.4 & 39.2 & 31.8 \\
\hline Horn of Africa & 12.2 & 8.6 & 10.6 & 14.7 & 12.7 & 4.6 & 3.9 & 9.6 \\
\hline North Africa & 0.2 & NA & 0.3 & 0.6 & 0.2 & 0.7 & 1.5 & 0.5 \\
\hline USA & 1.1 & 1.8 & 3.7 & 2.7 & 3.1 & 4.2 & 2.9 & 2.8 \\
\hline Latin America & 0.0 & NA & 0.0 & 1.1 & 1.3 & 1.2 & 3.7 & 1.0 \\
\hline Others & 14.9 & 30.1 & 5.6 & 7.7 & 6.3 & 5.7 & 5.0 & 10.8 \\
\hline
\end{tabular}

Source: Customs Department of Eritrea, Asmara

The destinations of Eritrea's exports and re-exports of commodities are shown in Table 4. From 1993 to 1997 Ethiopia was the main destination, usually with a share of over 60 per cent. The war caused exports to Ethiopia to drop to zero in 1999. Sudan has been the second largest destination, with an average of 19.3 percent. This declined gradually from 1993 to 1996 and started to increase again since then. In the five years from 1993-1997, Ethiopia and Sudan received a combined share of 77.8 per cent of Eritrea's exports. The decline inexport to Ethiopia has, as could be expected, seriously affected the country's income from foreign trade. Italy and Saudi-Arabia were the two other significant export-trading partners. Countries like Djibouti, UK, USA, Yemen, Germany and many other countries constitute the other destinations. Between 1993 and 1997, these countries received a combined average share of 14.2 per cent. The decline in exports to Ethiopia was associated with increased exports to the aforementioned destinations as Eritrea endeavoured to offset the loss of Ethiopian markets by seeking other markets. However, the rise of these countries' share to 57.8 per cent could not offset the negative effects of the collapse of trade with Ethiopia. 
Table 4 Direction of export and re-exports from Eritrea, 1993-1999 (Percentage Share)

\begin{tabular}{||l|c|c|c|c|c|c|c|c||}
\hline \multirow{2}{*}{ Country } & \multicolumn{1}{l}{ Year } & \multicolumn{1}{l||}{} \\
\cline { 2 - 9 } & $\mathbf{1 9 9 3}$ & $\mathbf{1 9 9 4}$ & $\mathbf{1 9 9 5}$ & $\mathbf{1 9 9 6}$ & $\mathbf{1 9 9 7}$ & $\mathbf{1 9 9 8}$ & $\mathbf{1 9 9 9}$ & Average \\
\hline Ethiopia & 62.4 & 52.3 & 67.0 & 65.8 & 63.4 & 26.5 & 0 & 48.2 \\
\hline Sudan & 22.3 & 14.6 & 14.4 & 10.1 & 16.6 & 27.0 & 30.3 & 19.4 \\
\hline Italy & 2.6 & 2.6 & 2.9 & 4.2 & 4.9 & 5.3 & 4.8 & 3.9 \\
\hline Saudi Arabia & 1.7 & 12.7 & 3.0 & 3.8 & 1.9 & 1.2 & 7.1 & 4.5 \\
\hline Others & 11.0 & 17.8 & 12.7 & 16.1 & 13.2 & 40.0 & 57.8 & 24 \\
\hline
\end{tabular}

Source: Customers Department of Eritrea, Asmara

Table 5 estimates the foreign exchange earnings from agricultural exports and the foreign exchange expenditures for agricultural imports for the seven years: 1993 to 1999 . The trade balance is an indication of the country's ability to pay for its imports with exports and can influence the value of its currency in world markets (Kohl's \& Uhl, 1998: 120). Eritrea had a negative trade balance during this period.

Table 5 Contribution of the agricultural sector to the balance of Trade of Eritrea (in millions of NAAFI)

\begin{tabular}{||c|c|c|c|c|c|c|c||}
\hline & $\mathbf{1 9 9 3}$ & $\mathbf{1 9 9 4}$ & $\mathbf{1 9 9 5}$ & $\mathbf{1 9 9 6}$ & $\mathbf{1 9 9 7}$ & $\mathbf{1 9 9 8}$ & $\mathbf{1 9 9 9}$ \\
\hline $\begin{array}{l}\text { Agricultural } \\
\text { exports }\end{array}$ & 113.120 & 259.077 & 319.281 & 244.217 & 221.020 & 148.283 & 95.974 \\
\hline $\begin{array}{l}\text { Imports of } \\
\text { agricultural } \\
\text { products }\end{array}$ & -244.338 & -551.970 & -530.110 & -737.865 & -747.548 & -595.295 & -933.395 \\
\hline $\begin{array}{l}\text { Estimated } \\
\text { balance }\end{array}$ & -131.218 & -292.893 & -212.829 & -493.648 & -526.528 & -447.012 & -873.421 \\
\hline
\end{tabular}

Source: Data for export and imports from Ministry of Agriculture and Customs Department Eritrea, Asmara

The estimates in Table 5 show that agriculture has consistently made a negative contribution to the balance of trade, and the agricultural trade gap has worsened considerably during the years under observation. This is very reasonable when the economic condition of the country is considered. The country became independent in 1991, after 30 years of devastating war. The country's infrastructure was in a very poor condition. Besides this, several other factors (like lack of credit for agriculture, shortage of skilled man power, low soil fertility, shortage of rainfall and traditional farming) contributed to the low productivity of the agricultural sector and its inability to fulfil the local demand. Hence, the country had a low level of food security. This resulted in the high 
level of imports of agricultural commodities. The border war with Ethiopia has further worsened agricultural productivity because the majority of the working population were involved with the war. This has also contributed to low exports of commodities during the three-year war from 1998 tot 2000.

The negative trade balance is becoming a very critical issue that could lead to severe constraints on the Eritrean economy. The rates of growth of imports and exports respectively, can be seen in Table 6. Growth of imports has completely overshadowed export growth. On average, imports grew by 33.12 per cent per year, compared to an average annual growth in exports of 8.51 per cent. During the first two years under discussion, export growth exceeded growth of imports, but declined from 1996 onwards.

Table 6 The annual growth in percentage of agricultural imports and exports in Eritrea from 1993-1999

\begin{tabular}{||c|c|c||}
\hline & \multicolumn{2}{|c||}{ Annual growth in percentage } \\
\hline Year & Imports & Exports \\
\hline 1994 & 125.90 & 129.00 \\
\hline 1995 & -3.59 & 23.24 \\
\hline 1996 & 38.66 & -23.50 \\
\hline 1997 & 1.31 & -9.49 \\
\hline 1998 & -20.36 & -32.90 \\
\hline 1999 & 56.79 & -35.27 \\
\hline Average & 33.12 & 8.51 \\
\hline
\end{tabular}

Source: Customs Department of Eritrea, Asmara

When one considers the relative contribution of agriculture to Eritrea's total export earnings, the gravity of the problem is highlighted by a negative trade balance in agricultural products, mainly food production,. For the period 1993 to 1999, agriculture contributed to more than half of the country's export earnings in 6 years out of seven as clearly shown in Table 7. Growth of agricultural production is urgently needed in order to reduce food imports, increase export of agricultural products and to stimulate agriculturally-based industry. 
Table 7 Percentage share of export earnings from 1993-1999

\begin{tabular}{||c|c|c||}
\hline \multirow{2}{*}{ Year } & \multicolumn{2}{|c|}{ Percentage share of export earnings } \\
\cline { 2 - 3 } & Agricultural sector & Non-agricultural sector \\
\hline 1993 & 54.1 & 45.9 \\
\hline 1994 & 65.2 & 34.8 \\
\hline 1995 & 60.3 & 39.7 \\
\hline 1996 & 46.9 & 53.1 \\
\hline 1997 & 59.0 & 41.0 \\
\hline 1998 & 75.2 & 24.8 \\
\hline 1999 & 58.7 & 41.3 \\
\hline
\end{tabular}

Source: Data taken from Customs Department of Eritrea, Asmara

\subsection{Horticultural potential}

There is historical that Eritrea has the potential for horticultural production to supply processing industries and earn foreign exchange. During the Italian colonial period and immediately thereafter when Eritrea was administrated by Great Britain (from approximately 1930 to 1950), horticultural products played an important role in the processing industry. Although these industries were small-scale, they were very successful in food processing. The horticultural sector earned sizeable amounts foreign exchange during that period. During the war of independence against Ethiopia, the contribution of this once flourishing export revenue earner shrank to negligible amounts.

The Eritrean economy had proven its ability to compete internationally in the export and horticultural products in the years before civil unrest and war. New efforts should focus on the development of the horticultural sector to achieve this outcome once again. Eritrea has a locational advantage, being on the main sea route between Europe and Asia, and is therefore in close proximity to the lucrative markets of both Europe and some rapidly growing Asian economies.

In a recent survey, the Ministry of Agriculture (1999) reported that horticultural holdings cover approximately 12000 hectares in various parts of the country. The number of holdings is approximately 34000 . Of this area, approximately 72 per cent has been cleared and developed, while the remaining 28 per cent is unutilised.

These holdings are distributed over various climatic zones, which makes the production of a variety of fruit and vegetable crops possible. In 1999, five horticultural crops occupied 78 percent of the land used for horticultural production: onions, bananas, potatoes, guavas and tomatoes. Yields are 
generally low, leading to high costs of production. There is certainly considerable scope to improve yields. Efforts to achieve this must include the provision of high quality services to this sector and the supply of improved quality inputs, mainly in the form of seed and vegetative plant material. Technological change in agriculture is typically associated with increased commercialisation and accompanied by increases in the use of purchased inputs, especially seeds and fertilizer (Delgado et al., 1988).

\subsection{Post-harvest problems: An impediment to agricultural growth}

In many developing countries, post harvest losses of agricultural commodities (including horticultural products) is the main impediment to realising a profit. The most effective method of making more food available is to limit postharvest losses (Berck \& Bigman, 1993). Food losses stem from poor postharvest handling and often, in the case of perishable products, from overproduction. In order to avoid wasteful overproduction, post-harvest loss reduction activities of perishables such as fruit and vegetables should begin even before the crop is planted. If access to consumer markets is limited (mainly due to insufficient transport infrastructure), then production of that specific type of crop should be reconsidered. The problem of food production for developing countries is far too often approached in terms of the mere production of sufficient amounts of food. Equally important issues relating to preservation and distribution that apply to the particular type of crop in the period between harvest and consumption are frequently neglected or even ignored. Postproduction operations in agriculture and horticulture include a wide range of functions which should be taken into consideration in order to supply good quality food, reduce transaction costs, and increase domestic welfare. The main post-harvest constraints in Eritrea are marketing services, transportation, storage, prices, diseases and pests, packaging and processing, and also equipment, quality, safety, and shelf life.

Poor transportation systems are a major marketing problem in Africa (Delgado et al., 1988; Abbot, 1986; Mittendorf, 1993). A study conducted by Ahmed and Rustage (1984) mentioned that agricultural marketing margins in five major African countries are typically twice as high as in four major Asian countries; higher transport costs account for 40 per cent of the difference. To large part, this may be due to a paucity of rural roads. Poor road conditions often cause truckers to refuse to go into rural areas because costs are too high (Mittendorf, 1993). Efficient transportation modes and routes are crucial to the success of an agricultural development strategy. Transportation costs seriously affect the comparative advantage of any country's agriculture. High transportation cost reduces comparative advantage of any export crop that Eritrea may produce and 
puts the country at a disadvantage for both exports and for competition with imports on local markets.

Poor storage facilities, the absence of an established food processing industry and poor food preservation technology all contribute to serious post-harvest losses. This exacerbates food shortages for poor consumers and also causes severe losses of revenue to farmers. It has for example been estimated that 31 per cent of banana production is lost due to post-harvest treatment (Table 8).

A low technological base, high-priced equipment and a lack of finance further worsen these problems.

Table 8 Post-harvest losses of banana production in Eritrea, 1999

\begin{tabular}{||l|l|c||}
\hline \multicolumn{1}{|c|}{ No } & Causes of losses & Losses in per cent \\
\hline 1 & In farmers field & 8 \\
\hline 2 & Transportation loss & 10 \\
\hline 3 & Storage & 8 \\
\hline 4 & In retail shop & 5 \\
\hline Total loss & & 31 \\
\hline
\end{tabular}

Source: Ministry of Agriculture, Preliminary survey on post harvest handling situation of bananas, 1999

The introduction and development of post-harvest technology including selection, preservation, packaging and processing in many countries has contributed to the promotion of agricultural production. Farmers' incomes have improved in due to the rising value of agricultural products. It is also important to develop techniques to preserve or maintain the quality, freshness and nutritional value of these agricultural products.

\section{PRIORITIES FOR AGRICULTURAL POLICY}

\subsection{General considerations}

Although the agricultural sector should be able to lead any form of economic recovery and growth, given the quantity of the country's resources and the large proportion of the population involved in agricultural production, it has not happened yet. A host of factors have restricted agricultural development, leading to insufficient production to even satisfy an underdeveloped local market. 
Because of these conditions, policy should be directed to remove or at least reduce factors impeding production and marketing on both local and foreign markets. This is in line with Myint's (1959) "vent for surplus" model, which in accordance with that of Adam Smith, regards international trade as the means to overcome the effects of narrow local markets on domestic production. According to Myint, it is necessary in the early growth stages in less-developed economies to achieve a transfer of labour efforts from subsistence to commercial production, thus from a subsistence to a monetary-based economy. An increase in working hours in relation to leisure is a second prerequisite, and an expansion of the amount of land under cultivation is a third condition for successful development. However, as shown by Hayami \& Ruttan (1985, Chapter 4), such development should include the development of effective technology suited to local natural and economic conditions. Such technology is the basis for further development.

Expansion of production occurs only if producers have the incentive to do so. This involves a positive marginal value product relative to their inputs of labour, land and capital, to the extent that it is more than their marginal resource cost. Increased returns to farmers are achieved by increased production and increased financial returns per unit produced. The latter means higher net product prices, which can largely be obtained by reduced marketing costs, reduced post harvest losses and reduced transaction costs. A fourth possibility is market expansion, which involves international trade.

Agricultural policy for Eritrea should include the considerations mentioned in the previous paragraph, and should be aimed at the elimination of any factors impeding the attainment of these objectives.

It is beyond the scope of this article to cover policy action in depth. Some general principles, based on experience elsewhere, will however be briefly outlined.

\subsection{Land tenure}

Eritrea has mixed systems of land tenure. The distribution of all land is not known at present. According to a recent horticultural survey, land under horticulture is divided as follows (Ministry of Agriculture, 1999):

Communal land: 42 per cent

Lease and Concession: 28 per cent

Private: 23 per cent

Other: 7 per cent 
Security of tenure in most areas is uncertain. The communal system as practised in Eritrea, involves redistribution of land by villagers approximately every seven years. This obviously impedes investment in improvements and the establishment of perennial crops.

Land tenure reform is needed in Eritrea. It should be noted that internationally, land tenure reform has had two objectives - equity, while maintaining productivity. In Eritrea, where such a large part of the population is dependent on subsistence, it is however still important not to neglect the productivity objective. Tenurial arrangements must enable land to achieve the following (Groenewald, 1998: 112-3):

- The land should foster agricultural production on a sustainable basis; tenure must contribute to conservation.

- $\quad$ Land must be able to provide increasing yield over time.

- Tenure must therefore provide incentives for investing capital on land. Land should be able to attract capital. The tenure system must also accommodate and provide incentives for new technology; the person who makes such investments or introduces such technology should be able to reap the benefits.

- The tenure system must stimulate the optimal use of the land.

- Land must be able to provide an attractive place to live to those who utilise it.

- Land and its tenure should be such that high calibre people are attracted to agricultural production.

The main requirements for successful land tenure are that it should provide incentives for people to produce and increase their production. This will have to be kept in mind in future tenure policy while ensuring that tenure changes do not lead to social upheaval. There is much literature available today covering more and less successful attempts of land reform. The experience of others should guide Eritrea in its tenure reform efforts.

\subsection{Transportation and storage}

Inadequate transportation facilities limit the possibilities of many producers to gain access to markets. It also makes access to inputs more difficult and costly, and lowers producers' returns. The absence of storage facilities aggravates seasonal market fluctuations and the level of post-harvest losses. In the light of critical food shortages, more attention should be given to this situation which causes a monetary loss of valuable products and nutritional loss of essential nutrients. Poor transport networks complicate problems where storage facilities are insufficient and thus influence prices of foodstuff (Spio, 1997). 
Rapid improvements in infrastructure are essential. This includes farm-tomarket roads, regional packing points, rail and port facilities, refrigeration facilities, access to modern telecommunication and accurate and timely product and price information. The support mechanisms of private and public sector and urgently need to be developed and ways to facilitate private sector investment need to be expanded. In the planning of a road network, it is essential to consider maintenance costs. The whole range of potential costs, fixed and variable, need to be evaluated against benefits. Over-investment in particular areas should be avoided; one-third of the value of road networks in sub-Saharan Africa has been lost through neglect, with government having been financially unable to perform maintenance (World Bank, 1987).

Better roads and lower transportation costs will enable the poor to reach markets to sell products and improve their chances to benefit from trade liberalisation.

Eritrea's inadequate infrastructure has hampered economic development and is an obstacle to economic integration, export growth, and the realisation of greater economic potential in general. In this regard in order to alleviate this problem, there should be more focus on the following: (1) road maintenance and rehabilitation; (2) encouraging the development of local road construction and maintenance contracting capability; (3) privatising state construction companies; (4) helping develop the private sector construction industry; (5) minimising the role of government in industry; (6) reducing the capital requirements for registration of contractors and (7) encouraging joint ventures with foreign contractors. By doing so, the government's primary role should be to guide development through appropriate policies, and its intervention is only justified where private sector involvement may not be practical or may be in conflict with national goals. Experience in many industries and countries have proven that privatisation improves efficiency, provided that ample competition is ensured (Groenewald, 1998).

\subsection{Marketing services}

Marketing involves all transactions and actions between the farmer and final consumer and also between the producer of inputs and the farmer. It involves all marketing functions and marketing institutions. The importance of marketing was perhaps best described by Peter Drucker (1976): "In every 'underdeveloped' country I know of, marketing is the most underdeveloped or least developed part of the economy.......Marketing would make the producers capable of producing marketable products by providing them with standards, with quality demands, and with specifications for their product. It would make the product capable of being brought to markets instead of perishing on the way. 
And it would make the consumer capable of discrimination, that is of obtaining the greatest value of this very limited purchasing power".

Government should try not to perform most of the marketing functions itself. International experience has clearly shown the inefficiencies of nationalised industries on a global scale. The major role of government should be the creation of an enabling environment, including a well-defined system of commercial law and the control of crime. Control of industry concentration should be part of the commercial law component. In a developing country such as Eritrea, government also has a task of empowerment. Without improved communication and information, marketing cannot be expected to develop optimally. Experience has shown that whilst some of these services can be provided efficiently by the private sector in developed economies, in developing economies the state should provide information networks.

In general the private sector runs marketing most effectively. The public sector's role must be to enable the private sector to operate efficiently. To enable the private sector to develop an effective marketing strategy, the following policy areas need to be considered: (1) focus on stronger participation of the private and co-operative trade to encourage the private sector to take greater initiative in the development and maintenance of marketing infrastructure; this requires a flexible government agricultural pricing policy; (2) the establishment of viable village banks, the mobilisation of personal savings, flexible interest rates, efforts to reduce financial transaction costs and developing sounder credit and investment policies; (3) decentralisation of government services and programmes and the promotion of self-help projects and (4) greater emphasis on the development of financial instruments to promote medium and long term investments in marketing infrastructures. It is essential that the government plays an active and facilitative role to encourage the private sector to support the agriculture sector (Van Rooyen \& Bembridge, 1998).

\subsection{Human capital development}

It is generally accepted that there is always a need for human capital development for economic growth and human development. Priority should be given to policies aimed at satisfying the most basic human needs and improvements in the quality of life, particularly of the most vulnerable groups. This requires a clear commitment in areas such as health, food and education. Training, which also plays a critical role in the development of human resources, should be directed towards teaching creative skills, specialisation and selfreliance, in such a way that everyone is given an equal opportunity to participate in the economic development process. Therefore general literacy and numeracy 
education, agricultural training and health education must be regarded as the essential prerequisite for agricultural development.

Increased agricultural productivity is needed for economic growth in Eritrea. This implies a wider spread use of more modern technology in many areas involving better seeding, fertilization, plant pest control, animal health and animal breeding, etc. The ability and desire to do so will largely be due to incentives provided by the markets and of the knowledge base. This emphasises the role of agricultural knowledge extension -importing knowledge on technical, economic and managerial aspects of modern farming. Research elsewhere has led to developments in for example, improved seed varieties and related technologies that greatly benefit developing countries. The adoption of these innovations by large numbers of farmers however, depends on their knowledge (Zaman \& Bose, 1974).

Appropriate models of knowledge extension should be selected and implemented by well-trained personnel. Tertiary training is very important for human capital development. The Eritrean government has started to address this need, given the support to the University of Asmara and the large number of Eritrean graduate students presently enrolled at South African universities with Eritrean government scholarships.

\subsection{Trade policy}

Eritrean trade policy must be aimed at improving local producers' access to foreign markets while simultaneously enabling those who achieve a desired level of efficiency, to compete on domestic markets. The main thrust must be widening of market access. It is also necessary to facilitate the importation of important agricultural and industrial inputs such as machinery, fertilizers and other chemicals at prices low enough to promote local competitiveness.

Tariff policy is one of the most important tools of foreign trade policy. Tariffs allow the country that levies them to influence the pattern and volume of its trade with the outside world. Tariffs have become the main tool through which a government can control the openness of the agricultural playing field (Van Schalkwyk et al., 1995). Eritrea should apply tariffs that will level the playing field between local and subsidised overseas producers, for Instance the EU. Eritrea should attempt to benefit from WTO rules which exempt developing countries from obligations to reduce tariffs. Tariffs on necessities for local production - e.g. machinery needed in agriculture and industry, should be kept low. 
It is also imperative for Eritrea to focus on access to foreign markets. The policy makers and planners should strive to allow the country to benefit from the opportunities provided by the US African Growth and Opportunity Act and also the EU Lomé Convention. Trade connections with African neighbours and also the Arab world - Eritrea's other close neighbours - should be strengthened. Eritrea must strive to derive benefits from her membership of COMESA and IGAD, and also from NEPAD.

A shift in industrial strategy is needed to change the high import dependence of Eritrean industries to more domestic resource-based manufacturing. Value adding of Eritrean-based raw materials should be encouraged for both local use and exports.

The success of trade as well as industrial policy, will ultimately depend on the soundness of Eritrea's macro-economic policies. Agriculture, trade, industry and other economic activities are irrevocably linked to a total economy which must be managed well by the authorities.

\section{CONCLUSION}

The problem of stimulating agricultural and other development in Eritrea does not have easy, simple solutions. As elsewhere in Africa, "the development will need to overcome a number of structural constraints arising from history and geography, and that goes beyond the very necessary but insufficient-bythemselves market reforms of the late 1980s and early 1990s". (Delgado, 1995 and 1999; Eicher, 1992). The great need is for smallholding farmers to become increasingly involved in production-for-sale of higher value per weight and more value added products in which Eritrea may have a comparative advantage.

There must be development of commercial and manufacturing services to support this and create non-agricultural employment and income. The infrastructure must be created to enable this process and more importantly, to reduce transaction costs. Farmers, traders and processor/manufactures alike need access to assets, information, services and remunerative markets (Delgado, 1999).

The Eritrean government must resist the temptation to achieve this on their own. Parastatal enterprises have generally had a poor record for bringing about largescale transformation in developing countries. Furthermore, there is evidence that parastatals in Africa have brought about higher marketing margins than in developing countries elsewhere (Koester, 1992). An analysis identified four reasons for this phenomenon (Ntangse, 1992): (1) The use of parastatals for 
political patronage; (2) their contributions to public financial crises, partially due to their need of large subsidies; (3) The burden to the economy caused by their high indebtedness and poor debt servicing performance; and (4) their high cost structures, coupled to the monopolistic conditions spawned by them.

The Eritrean government must furthermore realise the importance of agriculture and avoid the temptation to discriminate against the agricultural sector by limiting services to them or depriving their access to inputs at reasonable prices, or to profitable markets. Such policies have impeded economic development in many countries, including Nigeria (Ilorah, 2000), China (Lin, 1994) and India (Srinivasan, 1994).

\section{REFERENCES}

1 ABBOT, J.L. (1986) "Building food marketing infrastructure for economic development", In Kaynek, E (ed.) World Food Marketing Systems, Butterworths, London.

2 AHMED, R. \& RUSTAGE, N. (1984) Agricultural Marketing and Price Incentives: A Comparative Study of African and Asian Countries. International Food Policy Research Institute, Washington DC.

3 BERCK, P. \& BIGMAN, D. (1993) "The multiple dimensions of the world food problem", In Berck, P. \& Bigman, D. (eds.) Food Security and Food Inventories in Developing Countries, CAB International, London.

4 BRAND, S.S. (1969) "The Contributions of Agriculture to the Economic Development of South Africa since 1910”, B.Sc. (Agric) thesis, University of Pretoria.

5 DELGADE, C.L. (1995) "Africa's changing agricultural development strategies: Past and present paradigms as a guide to the future", International Food Policy Research Institute, Washington DC, Environment Discussion Paper, No. 3.

6 DELGADE, C.L. (1999) "Sources of growth in smallholder agriculture in sub-Saharan Africa: The role of vertical integration of smallholders with processors and marketers of high value-added items", Agrekon, 38 (Special Issue) 165-89.

7 DELGADO, C.L., MELLOR, J.W, \& BLACKIE, M.J. (1988) "Strategic issues in food production in sub-Saharan Africa", In Mellor, J.W. Delgado, C.L. \& Blackie, M.J. (eds.) Accelerating Food Production in Sub-Saharan Africa, Johns Hopkins University Press, Baltimore.

8 DRUCKER, P.F. (1976) "Marketing and economic development", In Enis, B.M. \& Cox, K.K. (eds.) Marketing Classics (4 ${ }^{\text {th }}$ ed.) Grid, Columbus. 
9 EICHER, C.K. (1992) “African agricultural development strategies", In Lall, F. \& Wangwe, S. (eds.) Alternative Development Strategies in subSaharan Africa, Macmillan, London.

10 ENKI, M. BELAY, K. \& DADI, L. (2001) "Determinants of adoption of physical soil conservation measuring in central highlands of Ethiopia: The case of three districts of North Shewa", Agrekon, 40: 293-315.

11 FUTUR, W. (1993) "Importance of trade and industrial policy for socioeconomic development: Reflections on the Eritrean economy", In Tesfagiorgis, G.H. (ed.) Emergent Eritrea: Challenges of Economic Development, The Red Sea Press, Trenton, New Jersey.

12 GROENEWALD, J.A., (1998) "Marketing and trade issues" In Van Rooyen, J., Groenewald, J., Ngqangweni, S \& Fenyes, T. (eds.) Agricultural Policy Reform in South Africa, AIPA/Francolin Publishers, Cape Town.

13 HAYAMI, Y, \& RUTTAN, V.W. (1995) Agricultural Development: An International Perspective, Johns Hopkins University Press, Baltimore.

14 ILORAH, R. (2000) "A classification of different phases of development in the export sector of Nigerian Agriculture", South African Journal of Economic and Management Farmers, NS3: 234-272.

15 KOESTER, U. (1992) "The Efficiency of agricultural markets in directing agricultural development", In Peters, G.H., Stanton, B.H. \& Tyler, G.J. (eds.) Sustainable Agricultural Development: The Role of International Co-operation, Dartmouth, Aldershot.

16 KOHLS, R.L. \& UHL, J.N. (1998) Marketing of Agricultural Products. $\left(8^{\text {th }}\right.$ ed.) Prentice-Hall, Upper Saddle River, NJ07458.

17 LIN, J.Y. (1994) "Chinese agriculture: Institutional changes and performance", In Srinivasan, T.N. (ed.) Agriculture and Trade in China and India, ICS Press, San Francisco.

18 MINISTRY OF AGRICULTURE (1997) Agricultural Brochure 19921996, Ministry of Agriculture, Asmara.

19 MINISTRY OF AGRICULTURE (1999) Eritrean Horticulture Survey, Ministry of Agriculture, Asmara, TCP/ER1/6714.

20 MINISTRY OF FINANCE (1999) Data on Financial Affairs, Ministry of Finance, Asmara.

21 MITTENDORF, HJ. (1993) "Improving physical marketing infrastructure in Africa through more self-help", In Abbott, J.C. (ed.) Agricultural and Food Marketing in Developing Countries. Selected Readings, CAB International, Wallingford.

22 MYINT, H. (1959) "The classical theory of international trade and the underdevelopment countries", Economic Journal, 68: 317-37.

23 NTANGSI, J. (1992) "Agricultural policy and structural adjustment in Cameroon”, In Peters, G.H. Stanton, B.F. \& Tyler, G.J. (eds.) Sustain- 
able Agricultural Development: The Role of International Co-operation. Dartmouth, Aldershot.

24 RUTTAN, V.W. (1983) Agricultural Research Policy, University of Minnesota Press, Minneapolis.

25 SEN, A. (1981) Poverty and Famines, Clarendon Press, London.

26 SHAPOURI, S. \& ROSEN, S. (1997) Food Security Assessment. United States Department of Agricultural, Economic Research Service, Washington, Report GFA-9.

27 SPIO, K. (1997) "The law food input farming sector in sub-Saharan Africa: Lessons and experience", Agrekon, 36: 231-50.

28 SRINIVASAN, T.N. (1994) "Indian Agriculture: Policies and performance", In Srinivasan, T.N. (ed.) Agriculture and Trade in China and India, ICS Press, San Francisco.

29 VAN ROOYEN, C.J. \& BEMBRIDGE, T.J. (1998) "Challenges for the restructuring of small farmer support services", In Van Rooyen, J., Groenewald, J., Ngqwangwani, S. \& Fenyes, T. (eds.) Agricultural Policy Reform in South Africa, AIPA/Francolin Publishers, Cape Town.

30 VAN SCHALKWYK, H.D., VAN ZYL, J. \& JOOSTE, A. (1995) "The effect of the exchange rate and international factors on the competitive position of South African wheat producers", Agrekon 34 : 250-53.

31 WORLD BANK (1987) Road Deterioration in Developing Countries.

32 ZAMAN, M.R. \& BOSE, S.R. (1974) "Extension service, education and agricultural development, with special reference to Bangladesh", In Islam, N. (ed.) Agricultural Policy in Developing Countries, Macmillan Press, London. 